\title{
Segmentation of honey consumers and identification of honey preference in Kota Bengkulu
}

\author{
Selmi $^{1,2)}$, Irnad ${ }^{3)}$, and Sistanto ${ }^{4}$ \\ 1) Graduate School of Agribusiness, Fac. of Agriculture, University of Bengkulu \\ 2) Dinas Peternakan dan Kesehatan Hewan Propinsi Bengkulu \\ 3) Department of Agriculture -Social Economic, Fac. of Agriculture, University of \\ Bengkulu \\ 4) Department of Animal Science, Fac. of Agriculture, University of Bengkulu
}

\begin{abstract}
As a country with a vast natural forest, Indonesia has a big potential production of honey. Honey is nutritious food produced by bees that mostly inhabit in the forest. Bengkulu is one of such place produced honey. Honey is considered as healthy supplement by consumer. Therefore, in this research, it has been studied the segmentation of consumers of honey and identification of honey attributes. This research was conducted in June- July 2015. There were 96 responsents gathered from eight (8) outlets selling honey products in Kota Bengkulu. Results showed that the consumers were young adults $(67 \%)$, women $(62 \%)$, married $(82 \%)$, S1 education $(56 \%)$, Kota Bengkulu domicile (88\%) with income range of $\mathrm{Rp} 2,100,000-5,000,000 /$ month $(62 \%)$. While the preference testing of honey products based on taste, aroma, and color had the score around 3.5- 3.7. This meant that respondents like the honey product.
\end{abstract}

Key words: honey, consumer, segmentation, preference, kota Bengkulu

Reference to this paper should be made as follows :

Selmi, Irnad, and Sistanto. 2020. Segmentation of consumers of honey and identification of honey preference in Kota Bengkulu. Agritropica: Journal of Agricultural Science. 3(2): 88-97. Doi: https:// doi.org/10.31186/Jagritropica.3.2.88-97

\section{INTRODUCTION}

Indonesia is very suitable for the business of beekeeping, because the state of Indonesia is very rich variety of flowering plants and crops that can be used as a food source for bees cultivated throughout the year. When the flowering season arrives, honey production will be very abundant. In addition, Indonesia has vast natural forests, around 143 million hectares with a variety of flowering trees producing nectar and pollen. Potential forest resources are quite extensive in Indonesia, making Indonesia has a comparable one to other countries. Economic development in Indonesia should be improved by taking advantage of existing forest resources so that it can be a competitive advantage and can be a driving force for the growth of national economic (Novandra and Widnyana, 2013).

Honey is one of the bee products that has long been known by people in the world, including Indonesia. Indonesia with a current population of nearly reach 240 million inhabitants, is the largest population of all four of the world requires quite a lot. According to the Pusat Perlebahan Nasional (2008), Indonesia has a honey consumption level of around 15 grams / capita / year, whereas in developed countries such as Germany, Japan, Britain and France the level of honey consumption has reached 700 - 1,500 grams / capita / year. The low level of honey consumption is partly due to the fact that many people 
consider that honey is only useful as a medicine, so the level of consumption of Indonesian people on honey is still very low.

Honey is a nutritious beekeeping product and has an important role not only as a food ingredient, but also has benefits as medicine, health care and as a food supplement. It has high nutritional value make honey nice consumed either for children, adults and the elderly.The amount of honey in the country needs caused by product produced by bees is not only used for consumption per person but is also required by the industry of beverages, pharmaceuticals, dairy, bakery, soap and Sampho. Besides some cosmetic products, grandmother products- honey bee products (Winarno, 2010).

Seeing the potential of Indonesia and seeing the many benefits and benefits of honey, the government since the early 70s has been conducting honey bee farming. According to data from the Departemen Kehutanan Direktorat Jenderal Planologi Kehutanan (2009) currently has developed hundreds of local bees, both managed on a large scale and small scale as a side business. The number of competitors in memp $r$ oduksi honey cause the development of honey and honey marketing should be able to create added value (added value) of the product so as to compete with other manufacturers. The added value of this can be done by the manufacturer to produce a high quality product, best packaging, hygenic accordance with the tastes and preference of consumers (Rosalina et al., 2010 ).

Not to ensuring the quality of honey by the breeder who sold in the market makes people become hesitant to buy a product of honey. The price of honey also varies greatly when viewed from the type and origin of the region. This will cause public confidence in the honey product diminishing. The problem that arises at the farm level is the low absorption of processing technology and product supply. This has an impact on the selling price of the product, because the product is made to be able to meet consumers need (Suranto, 2005). Pure honey is produced at the farm level is usually not through the processing of good and hygienis, already contaminated product (packaging), it was also not attractive so it will affect the purchasing decisions of consumers of pure honey pure in Kota Bengkulu (Rosalina et al., 2010 ) .

The number of new competitors in the business of honey products, especially local honey with various labels and form an attractive packaging as well as the change in behovior of consumers are expected to have an impact on consumer preferences in the purchase of honey products. Saepudin (2014) states that all outstanding brands of packaged honey in Bengkulu has been testing the organoleptic turned out to show different qualities and less well with water levels high exceeding the Indonesian National Standard (SNI) .

Honey has a large market share and good prospects so much honey beekeepers to compete in the competition in honey bee breeding business. Bee products are very promising if used as a business opportunity. There are some honey beekeepers who sell honey without thinking Quality of making the position of bee farmers, especially small scale today is becoming weaker. Marketing of honey farmers in Bengkulu is often selling its products directly to consumers. Honey is sold in bulk / 
bottles that do not use brands with specific shapes and sizes .

Seeing these conditions, a study of the consumers behavior on honeybees can be used as a basis for decision-making by businesses. This can be used as a solution for honey farmers and business people in order to increase the marketing volume of their products. In the case of marketing the most difficult condition is to maintain consumers to always use their superior products by creating loyalty for customers by maintaining the availability and consistency of the quality of honey products. Applying the right marketing strategy is needed to increase product sales in the market. One of the marketing strategies that are usually used by companies are the concept of $4 \mathrm{P} /$ marketing mix consisting of product, price, promotion and the place (where) (Kotler and Keller, 2006 ). Thus, the factors that exist in the marketing mix are the product / attribute variables that are considered important by consumers and are used as the basis for purchasing decisions.

Based on the description above, the problem presented in this study are the segmentation of consumers of honey products and identification of honey product preference.

\section{MATERIALS AND METHODS}

\section{Research Location and Time}

Determining the location is done on the outlet-outlet honey in Kota Bengkulu. This selection is done by purposive (intentional) with the following considerations:

1. Bengkulu City as the center of the city has several shops / outlets that sell honey products. It is an easily accessible market for the people of Bengkulu and outside Bengkulu.

2. Outlets that sell quite a lot of honey products, with more than 5 variants and inventory and continuity of goods there every time.

3. Honey outlets were selected in the largest shops and supermarkets in Bengkulu City with the highest sales / turnover. The selection of outlets is based on surveys and interviews, that is, outlets that make sales in one day at least 5 times. The determination of outlets is done through a survey for 3 days on selected oulet, after that the number of sales is averaged.

Locations of the study conducted were in 8 stores / outlets of honey and herbs as well as supermarkets are big enough. The outlets of honey that serve as the location of the study are: outlet honey and herbal "Salsabila" and "Mujtahid located in Pagar Dewa, outlet honey and herbal center Rawamakmur, honey and herbal outlets Al Fatih East Circle, Giant (Mega Mall), Hypermart (Bengkulu Indah Mall), Mini Market 88 and Faten Farma Pharmacy. And the collection of data were done during the months of June - July 2015.

\section{Determination and Retrieval of Respondents}

Determination of sample size in this study was carried out using the Virtusio formula . According to Virtucio in Treasure (2005), this method is used because the population is difficult to know in advance. To determine who will be the respondent in this study is by using the accidental sampling method.

According to Sugiyono (2006), accidental sampling technique is a 
technique for determining respondents based on anyone who incidentally is considered suitable as a source of data, then a questionnaire were given. If the person fulfills the criteria for being a respondent then that person is asked to be willing to be interviewed by answering the questions in the research questionnaire.

Determination of respondents was carried out in a proportional simple random sampling method. Based on Table 1, obtained amount of each honey outlet is respectively 16 respondents at the outlet of honey Salsabila, Honey and Herbs Rawa Makmur and Giant supermarket and Paten pharmacy Farma, then 8 respondents, each in outlet honey Mujtahid Pagar Dewa, Hypermart, Al Fatih Lingkar Timur, and MM 88.

Table 1. Determination of respondents of honey outlet

\begin{tabular}{|c|c|c|c|c|c|c|}
\hline No & Honey Outlet & Location & $\begin{array}{l}\text { Honey } \\
\text { Variation }\end{array}$ & $\begin{array}{c}\text { Estimate } \\
\text { Turnover } \\
\text { (Rp / } \\
\text { month) }\end{array}$ & $\begin{array}{c}\text { Proportion } \\
\text { Samples (\%) }\end{array}$ & $\begin{array}{c}\text { Total } \\
\text { Respondent }\end{array}$ \\
\hline 1 & Salsabila Herbal & $\begin{array}{l}\text { Pagar } \\
\text { Dewa }\end{array}$ & $\geq 5$ types & 2.000 .000 & 15,9 & 16 \\
\hline 2 & $\begin{array}{l}\text { Honey and } \\
\text { Herbs }\end{array}$ & $\begin{array}{c}\text { Rawa } \\
\text { Makmur }\end{array}$ & $\geq 5$ types & 2.000 .000 & 15,9 & 16 \\
\hline 3 & Mujtahid Herbal & $\begin{array}{l}\text { Pagar } \\
\text { Dewa }\end{array}$ & $\geq 5$ types & 1.000 .000 & 7,9 & 8 \\
\hline 4 & M M 88 & Suprapto & $\geq 5$ types & 1.000 .000 & 7,9 & 8 \\
\hline 5 & Giant Super & $\begin{array}{l}\text { Mega } \\
\text { Mall }\end{array}$ & $\geq 5$ types & 1.000 .000 & 15,9 & 16 \\
\hline 6 & Hypermart & BIM & $\geq 5$ types & 1.000 .000 & 7,9 & 8 \\
\hline 7 & Al Fatih Herbal & LK.Timu & $\geq 5$ types & 1.000 .000 & 7,9 & 8 \\
\hline 8 & Paten Pharmacy & Suprapto & $\geq 5$ types & 2.000 .000 & 15.9 & 16 \\
\hline Total & & & & 12.000 .000 & 95,9 & 96 \\
\hline
\end{tabular}

Source: Direct Survey and Interview (2015)

Data Types and Sources

The data used in this study are primary and secondary data. Primary data, namely data that is directly and deliberately obtained from data sources by researchers for specific purposes (Surakhmad, 1998). Primary data in this study are data obtained from respondents directly by researchers by giving structured questions to the questionnaire, interview and through observation in the field. The data taken is about the reasons and factors that influence the purchase of honey consumed by consumers.
Secondary data is data that has already been obtained from people outside the study itself. Secondary data needed in the form of honey production data, honey imports, national honey consumption data and other literature. Secondary data were obtained from agencies related to this study, namely from the Ministry of Forestry, National Honey Beekeeping Center, National Honey Beekeeping Association, articles and previous researches.

\section{Descriptive Analysis}

Based on the purpose of this study to determine the segmentation of 
honey consumers in the city of Bengkulu can be seen based on age, gender, religion, education, income, employment, marital status, residence. Analysis of the data used is descriptive analysis by tabulating data obtained from questionnaires against respondents. According to Sugiyono (1998) descriptive analysis is the means used to explain everything about the data obtained and presented in tables, verbal descriptions, diagrams so that the data easier to understand.

This descriptive analysis is used to describe the characteristics of consumers and the stages of the process of honey purchasing decisions in Bengkulu City obtained through a questionnaire. Descriptive analysis uses a frequency table that is the presentation of data and information in the form of a simple table that contains the same grouping of answers. The results obtained are then presented based on the number of respondents. The biggest percentage of each outcome is the dominant factor of each variable analyzed.

\section{Marketing Environment}

The marketing environment is actors and forces that are outside the management function. Thus, it will affect the ability of marketing management to develop and foster successful transactions with its target customers. The interaction between the internal environment and the external environment of marketing has a bearing on marketing objectives and strategies. The external environment can explain the opportunities and threats for the company's organization, while the internal environment can show the strengths and weaknesses of the organization.
Internal environment is the company's internal activities that can be controlled. This means that to achieve the objectives and carry out marketing strategies, marketers must be able to control or regulate the operation of these activities as desired by the company. Therefore internal environment analysis is a determining factor for developing marketing strategies. According to Jauch and Glueck (1995) the internal environment is divided into six factors namely human resources, production, technology, finance, marketing and research and development. Variabel variable estimators within the internal are quality products, price strategy, product packaging, hospitality of employees, hospitality of employees, product variations, discounted price promotion activities, number of agents, strategic location.

In its operations, the company's marketing system is influenced by environmental factors of the system, both inside and outside the company. Factors included in the external environment is generally not controllable by management. The external factors are divided into two groups: (1) the first group is mako factors such as culture, regulations, and economic conditions, and (2) the microenvironment of companies, such as suppliers, marketing intermediaries, and buyers. Although these elements are outside the company, but have a closed relationship with certain companies. The estimating variables in the external environment are determination of selling prices, bargaining power with buyers, bargaining power with buyers, consumer confidence,bargaining power with suppliers, the many types of honey brands, relatively high competition, 
difficult bureaucracy for exports, uncertain economic conditions.

The level of preference for the taste of honey on the market is felt by the taste buds in the form of sweet, sour and bitter tastes perceived by respondents as measured in a score unit (1- 5).

Table 2. The level of preference for honey

\begin{tabular}{cccccc}
\hline Aspect & 1 & 2 & 3 & 4 & 5 \\
\hline Taste & do not like & $\begin{array}{c}\text { do not like } \\
\text { it much }\end{array}$ & pretty like & like it & love it \\
\hline Aroma & very poor & not good & neutral & $\begin{array}{c}\text { pretty } \\
\text { good }\end{array}$ & very good \\
\hline Color & do not like & $\begin{array}{c}\text { do not like } \\
\text { it much }\end{array}$ & pretty like & like it & love it \\
\hline
\end{tabular}

Information on the product is in the form of information on expired date, license P-IRT of BPOM, the specific benefits of honey, storage conditions, and the correct way of consuming honey. Viscosity is the level of consistency of honey felt by respondents that is smooth texture like no sediment, not sticky on the tongue so it is easier to consume.

Color is a honey attribute that can be seen directly that can show the origin of honey and honey quality. Benefits are the value obtained by respondents after consuming honey at the cost they have incurred for the price of the product.

Brand is a name, term, sign, symbol, design or combination that is used to identify a product so that it can be differentiated from competitors 'products and also describe consumers' perceptions of quality and image in the form of assessments and beliefs, both positive and negative.

1. Authenticity is a condition of honey that is not mixed with other substances so that the benefits are maintained and the quality is good.

2. Volume is the amount of honey in one package. This attribute evaluation illustrates the suitability between the many variations of the available volume in the market with the needs of consumers.

3. Advertising and promotion are a series of ways that can be used to introduce and market honey so consumers are interested in consuming it.

4. The ease of obtaining products is a way that does not complicate consumers in purchasing products.

\section{RESULTS AND DISCUSSION}

\section{Profile of Honey Outlet}

The Herbal Honey Center, located on Jalan Kalimantan Rawa M akmur, was founded by Mr. Iyan Hadiyah in June 2014. The Honey and Herbal Center sells a wide variety of honey and herbal products, besides selling other nonhoney products such as: Gold G, Sari Kurma, Herbal Coffee and others. The Honey and Herbal Center is a distributor of honey and herbs for the city of Bengkulu and outside the city of Bengkulu. In the city Honey and Herbal Centers market their products to pharmacies in the city of Bengkulu, including several Pharmacies.

The "Al- Fatih" Herbal Shop was founded by Mr. Nusiranto in 2007. The honey outlet, taking the name "Al-Fatih", 
is expected to be easy for consumers to remember. Especially those who are Muslim and have a special meaning in the hearts of consumers. So with these good words and have a good meaning, consumers are expected to be more interested in making honey purchasing decisions, especially at the "Al-Fatih" outlet in Bengkulu. The location of the outlet is at Jalan Salak Raya No. 59 Lingkar Timur, where it is located on the edge of the highway, close to the Panorama market so it is easy to find it. The "Al-Fatih" honey outlet business has expanded its business as a Multi Level Marketing business as a center for HPAI products in Bengkulu Province.

Stores Herbs and Honey Salsabila " founded by Mr. Ismawanto the month September Year 2015. The word "Salsabila" is name of her first child. The location of the outlet is on Jalan DP Natanegara Pagar Dewa. The "Salsabila" honey and herbal center, besides selling honey and herbal products, also sells Hajj and Umrah supplies and Muslim clothes .

In addition to the above outlets, honey can also be found in Supermarkets, Supermarkets, Mini Markets and Pharmacies such as: Hypermart, Giant, MM 88 and Patent Pharmacy. There are also consumers who buy honey from honey producers in the city of Bengkulu.

\section{Honey Consumer Segmentation}

Consumer characteristics

observed in the research are the consumers of honey in the outlet that are in Bengkulu City, include: age, sex, marital status, occupation, education, income, and expenses. Consumers aged between 21-45 years are more dominant because generally in this age group consumers can think logically and rationally in determining which products are useful for health and fulfill their appetite and health. In general, adult consumers tend to have a fairly high level of preference for health products, one of which is honey which has many health benefits.

Consumers who are in the age range will be more flexible in choosing products according to their needs because financially consumers are more capable in choosing health products such as honey. This is consistent with the theory put forward by Sumarwan (2004) that age influences consumer tastes in choosing the products they use.

Table 3. Honey consumer segmentation

\begin{tabular}{|c|c|}
\hline Segmentation & Amount (\%) \\
\hline Young adults (21-45 yrs) & 67 \\
\hline Medium (46-70 yrs) & 31 \\
\hline Old (71-92 yrs) & 2 \\
\hline Man & 38 \\
\hline Woman & 62 \\
\hline Married & 82 \\
\hline Not Married & 18 \\
\hline Civil servants & 37 \\
\hline Private & 21 \\
\hline S1 education & 56 \\
\hline S2 Education & 20 \\
\hline High School & 13 \\
\hline Middle School & 2 \\
\hline Elementary school & 2 \\
\hline $\begin{array}{l}\text { City of Bengkulu } \\
\text { domicile }\end{array}$ & 88 \\
\hline $\begin{array}{l}\text { Domicile in Central } \\
\text { Bengkulu and Seluma }\end{array}$ & 12 \\
\hline Income (Rp/month) & $\begin{array}{l}\text { Amount } \\
(\%)\end{array}$ \\
\hline$<\_2,000,000$ & 24 \\
\hline $2,100,000-5,000,000$ & 62 \\
\hline $5,100,000-10,000,000$ & 8 \\
\hline$>10,000,000$ & 6 \\
\hline
\end{tabular}

More women buy honey than men. Women usually have more role in 
the decision to purchase household products. This is in accordance with the theory put forward by Lury (1998) namely that $80 \%$ or more of the decision on the purchase or consumption of goods is determined by women. Indonesian culture is consistent with this theory that women are more responsible for household purchasing decisions. In addition, women are also more selective in making decisions about purchasing products for consumption.

The majority of consumers are married with a percentage of $82 \%$ and unmarried with a percentage of $18 \%$. The marital status of consumers can have a strong influence on consumer behavior. The purchasing decisionmaking process that occurs to married consumers tends to have an element of influence from their spouse or family members. Married consumer relatively more cautious and deliberate in making a purchase of a product, while consumers who are not married are relatively more freedom in determining the choice of consuming a product. Marital status will affect the desire to live healthy in order to live longer with family. So that, marital status will affect to consume health products such as honey.

The consumers who have the type of work as civil servants with a percentage of $37 \%$. Types of jobs as civil servants are jobs that have the opportunity to have relatively high wages so that financially consumers can be better able to choose health products for consumption. This is in accordance with the opinion of Kotler (2002) which states that one's work also affects consumption patterns, in this case marketers must be able to identify professional groups that have strengths above the average honey product and companies must be able to classify their products for professional groups.

The majority of honey consumers in Bengkulu City have a Bachelor's level education with a percentage of $56 \%$. The education level $S 1$ is the level of education are high, education levels indicate the level of knowledge of consumers to information about honey . So it can be concluded, honey consumers in Bengkulu are selective in choosing the type of honey that will be consumed. However, there are also other levels of education in consuming honey in Bengkulu, namely elementary school with a percentage of $2 \%$, junior high school with a percentage of $2 \%$, high school with a percentage of $13 \%$, Diploma with a percentage of $6 \%$, S2 with a percentage of $20 \%$, and S3 is $1 \%$. A high level of education will affect the purchasing decision process because consumers who have a high level of education will know more about what they need and benefit them especially in terms of health. This is in accordance with the opinion of Hanafiah and Saefuddin (1986) that highly educated consumers tend to choose food ingredients with higher quality than consumers with low education.

A person's education level affects patterns of thinking, how to view a product. Consumers who have better education will be more responsive to information, education also influences consumers in product selection (Sumarwan, 2002) and that someone who has knowledge and a high level of education tends to choose a product better quality than those with low education. Apart from looking at the quality of the food it consumes, consumers with much higher education also look further at the ugliness and risk in consuming products, and tend to 
behave more critically in the purchase and selection of a product.

Honey consumer comes from Kota Bengkulu at $88 \%$, followed by the District of Bengkulu Tengah and Kab. Seluma, 6\% each. The location where consumers live will affect their consumption patterns for a product. Consumers highly consider access from their place of residence to the location of product sales (Sumarwan, 2005). Consumers generally buy products in areas that are easily accessible.

Consumers of honey in Kota Bengkulu have incomes averaging Rp. 2,100,000 - Rp. 5,000,000 with a percentage of $62 \%$. Consumers with an average monthly income of between $\leq$ Rp. 2,000,000 by $24 \%$, in the range of Rp. $5,100,000$ - Rp. $10,000,000$ by $8 \%$, and in the range between $>$ Rp. $10,000,000$ by 5 $\%$. This shows that honey is a food product that has high efficacy with relatively high prices. Income will affect the decision process and consumption patterns of a person. Mangkunegoro (1988) states that respondents who have high incomes tend to spend their money to buy consumer goods they like. The amount of income can describe the amount of purchasing power of a consumer.

\section{Honey Preference}

The level of preference for the taste, aroma, and color of honey on the market is shown in this Table 4.

Table 4.The level of preference for honey

\begin{tabular}{ccc}
\hline Aspect & Score & Quality \\
\hline Taste & 3.7 & Pretty like- like \\
\hline Aroma & 3.6 & Pretty like- like \\
\hline Color & 3.5 & Pretty like- like \\
\hline
\end{tabular}

Testing on honey showed that respondents had the preferences on taste, aroma, and color were about the same score, around 3.5- 3.7. It meant that honey was prefered by the respondents.

\section{CONCLUSION}

There were 96 responsents gathered from eight (8) outlets selling honey products in Kota Bengkulu. Results showed that the consumers were young adults (67\%), women (62\%), married (82\%), S1 education (56\%), Kota Bengkulu domicile (88\%) with income range of $\operatorname{Rp} 2,100,000-5,000,000 /$ month $(62 \%)$. While the preference testing of honey products based on taste, aroma, and color had the score around 3.5-3.7. This meant that respondents like the honey product.

\section{REFERENCES}

Badan Pusat Statistisk, 2013. Bengkulu Dalam Angka. Badan Pusat Statistik Kota Bengkulu. Bengkulu

Bappenas. 2002. Budidaya Lebah Madu. http : // www.warintek.bantul.co.id. Diakses pada 9 Oktober 2008.

Departemen Kehutanan Direktorat Jenderal Planologi Kehutanan. 2009. Eksekutif Data Strategis Kehutanan 2009. Jakarta: Departemen Kehutanan RI.

Hanafiah dan Saefuddin. 1986. Tata Niaga Hasil Perikanan. UI Press. Jakarta.

Jauch dan Glueck. 1995. Manajemen Strategi dan Kebijakan Perusahaan. Jakarta: Erlangga. 
Kotler, P., dan K. Keller. 2006. Manajemen Pemasaran Jilid 1. PT. Macana Jaya Cemerlang.

Kotler, P., 2005. Manajemen Pemasaran, Analisis, Perencanaan, Implementasi dan Pengendalian. Erlangga, Jakarta.

Kotler, P. 2002. Manajemen Pemasaran. Edisi Milineum. Jilid 1 \& 2. PT. Prehalindo. Jakarta.

Lury, 1998. Peran Karakteristik Merek, dan Karakteristik Hubungan Pelanggan. Jurnal Manajemen. 6 (1): 1-8

Mangkunegoro. $\quad 1988 . \quad$ Perilaku Konsumen. PT. Eresco. Bandung.

Novandra, A., and I. M. Widnyana. 2013. Peluang pasar produk perlebahan Indonesia. Balai Penelitian Teknologi Hasil Hutan Bukan Kayu, 13.

Pusat Perlebahan Nasional, 2008. Lebah Madu, Cara Beternak dan Pemanfaatannya. PS. Jakarta.

Rosalina, Y., Alnopri, and Prasetyo. 2010. Disain Kemasan Untuk Meningkatkan Nilai Tambah Madu Bunga Kopi Sebagai Produk Unggulan Daerah. Jurnal Agroindustr 2 (1) : 1-6
Saepudin, R. 2014. Kualitas Madu Yang Beredar di Kota Bengkulu Berdasarkan Penilaian Konsumen dan Uji Secara Impirik. Jurnal Sain Peternakan Indonesia, 9 (1): $1-10$

Sugiyono, 1998. Metode Penelitian. Gramedia Pusat Utama. Jakarta

Sugiyono, 2006. Statistik Untuk Penelitian, Alfa Beta. Bandung

Sumarwan, B. 2005. Lebah Madu. Agro Media Pustaka. Jakarta.

Suranto, A. M. Riza. 2005. Penentuan Strategi Pemasaran Berdasarkan Perilaku Konsumen dengan Metode Diskriminasi. Jurnal Ilmiah Teknik Industri, 4 (1) : 18 27

Surakhmad, W. 1998. Pengantar Penelitian Ilmiah dan Dasar Metode Teknik. Tarsito. Bandung

Swastha, B. 2002. Azaz-azaz Marketing. Edisi 3. Liberty Yogyakarta. Yogyakarta.

Winarno. 2010. Madu, Teknologi, Khasiat dan Analisa. Pusat Penelitian dan Pengembangan Teknologi Pangan, IPB. Bogor. 